\title{
Penilaian Kinerja Keuangan menggunakan Economic Value Added (EVA) dan Market Value Added (MVA) dengan Time Series Approach pada Industri Semen di Indonesia
}

\author{
Nardi Sunardi ${ }^{*}$ \\ *) Universitas Pamulang, dosen01030@unpam.ac.id
}

\section{ARTICLES \\ INFORMATION}

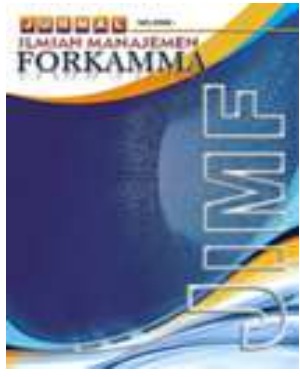

JURNAL ILMIAH MANAJEMEN FORKAMMA

\author{
Vol.3, No.2, Maret 2020 \\ Halaman : $184-194$ \\ (C) LPPM \& FORKAMMA
}

Prodi Magister Manajemen

UNVERSITAS PAMULANG

ISSN (online) : 2599-171X

ISSN (print) : :2598-9545

\section{Keyword:}

Kinerja Keuangan; Economic Value Added; Market Value Added (MVA)

JEL. classification :

C33, G21, G34, N25

\section{Contact Author : \\ PRODI \\ MAGISTER MANAJEMEN \& FORKAMMA UNPAM \\ JL.Surya Kencana No.1 Pamulang \\ Tangerang Selatan - Banten \\ Telp. (021) 7412566, Fax (021) 7412491 \\ Email : \\ jurnalforkamma.unpam@gmail.com}

Tujuan penelitian ini untuk mengetahui kinerja keuangan Industri Semen di Indonesia yang listing di Bursa Efek Indonesia Periode 2013-2018 dengan pendekatan Economic Value Added (EVA) dan Market Value Added (MVA) dengan Time Series Approach, Hasil penelitian ini berdasarkan Economic Value Added (EVA) menunjukkan bahwa PT. Holcim Indonesia Tbk. hasilnya negatif dikatakan berkinerja tidak baik. PT. Indocement Tunggal Prakarsa Tbk., PT. Semen Baturaja (Persero) Tbk. dan PT. Semen Indonesia (Persero) Tbk. adalan positif dikatakan berkinerja baik. Berdasarkan Market Value Added (MVA) PT. Semen Baturaja (Persero) Tbk. dan PT. Holcim Indonesia Tbk. hasilnya negatif dikatakan berkinerja tidak baik. PT. Indocement Tunggal Prakarsa Tbk. dan PT. Semen Indonesia (Persero) Tbk. adalan positif dikatakan berkinerja baik. Penilaian Economic Value Added (EVA) dan Market Value Added (MVA) pada Industri Semen di Indonesia sebesar 12,17 menunjukan hasill positif, Hal ini menunujukkan bahwa Industri Semen di Indonesia secara keseluruhan dikatakan berkinerja BAIK .

The purpose of this study was to determine the financial performance of the Cement Industry in Indonesia which was listed on the Indonesia Stock Exchange for the 2013-2018 period with the Economic Value Added (EVA) and Market Value Added (MVA) approaches with the Time Series Approach. The results of this study were based on the Economic Value Added (EVA ) shows that PT. Holcim Indonesia Tbk. negative results are said to perform poorly. PT. Indocement Tunggal Prakarsa Tbk., PT. Semen Baturaja (Persero) Tbk. and PT. Semen Indonesia (Persero) Tbk. positive is said to perform well. Based on Market Value Added (MVA) of PT. Semen Baturaja (Persero) Tbk. and PT. Holcim Indonesia Tbk. negative results are said to perform poorly. PT. Indocement Tunggal Prakarsa Tbk. and PT. Semen Indonesia (Persero) Tbk. positive is said to perform well. Economic Value Added (EVA) and Market Value Added (MVA) assessments in the Cement Industry in Indonesia of 12.17 indicate a positive result. This shows that the Cement Industry in Indonesia as a whole is said to good perform. 


\section{A. PENDAHULUAN}

Laporan keuangan ini sudah menjadi kebutuhan utama pihak-pihak dalam proses pengambilan keputusannya dalam perekonomian modern laporan keuangan sudah merupakan media penting dalam proses pengambilan keputusan ekonomi. Laporan keuangan perusahaan lazim diterbitkan secara periodik bisa tahunan, semesteran, triwulan, bulanan, bahkan bisa harian. Penilaian kinerja keuangan perusahaan sangat penting bagi perusahaan untuk mengetahui peningkatan kinerja perusahaan yaitu pendapatan perusahaan dengan meningkatkan pendapatan yang besar untuk mempertahankan kelangsungan jalannya perusahaan. Perusahan yang ingin tetap mempertahankan kelangsungan usaha perlu mengadakan analisa atau penilaian terhadap kinerja keuangan karena analisa ini menjadi salah satu faktor penunjang dalam menjalankan roda perusahaan dalam menjalankan proses bisnis dengan persaingan yang sangat ketat. Pengukuran kinerja keuangan merupakan salah satu strategi untuk membuat kebijakan manajerial khususnya kebijakan keuangan supaya perusahaan tetap mampu mempertahankan esitensinya.

Pendekatan dengan analisis keuangan pendekatan Economic Value Added (EVA), Financial Value Added (FVA) dan Market Value Added (MVA) dengan Time Series Approach merupakan salah satu alat ukur kinerja keuangan yang relevan digunakan untuk melihat sejauh mana efektivitas perusahaan dalam pengembalian atas investasi dilakukan oleh perusahaan dengan menggunakan ukuran kinerja yang dilihat dari nilai tambah (Value Based) yaitu konsep Economic Value Added (EVA), Financial Value Added (FVA) dan Market Value Added (MVA)

Objek penelitian dilakukan pada perusahaan go public pada Industri Semen di Indonesia yang Listing di Bursa Efek Indonesia Tahun 2013-2018 yaitu PT. Indocement Tunggal Prakarsa Tbk., PT. Semen Baturaja (Persero) Tbk., PT. Holcim Indonesia Tbk., dan PT. Semen Indonesia (Persero) Tbk.

Economic Value Added (EVA) atau nilai tambah ekonomi adalah tolak ukur kinerja keuangan dengan mengukur perbedaan laba usaha setelah pajak (NOPAT) dan beban modal untuk periode tersebut (yaitu, produk dari biaya modal perusahaan dan modal yang diinvestasikan pada awal periode). Sedangkan Market Value Added (MVA) adalah perbedaan antara nilai pasar ekuitas perusahaan pada periode tertentu dengan nilai ekuitas yang dipasok para investornya atau alat untuk mengukur berapa banyak kekayaan suatu perusahaan yang telah diciptakan untuk saat tertentu. Metode penelitian yang digunakan adalah metode deskriptif kuantitatif dengan sampel perusahaan Industri Konstruksi (BUMN) di Indonesia yang Listing di Bursa Efek Indonesia Tahun 2013-2017 .

Berdasarkan latar belakang masalah di atas maka masalah yang akan dibahas dan dicari jawabannya dalam penelitian ini adalah :

1. Penilaian Kinerja Keuangan Industri Semen yang listing di Bursa Efek Indonesia Tahun 2013-2018 berdasarkan metode Economic Value Added (EVA) ?

2. Penilaian Kinerja Keuangan Industri Semen yang listing di Bursa Efek Indonesia Tahun 2013-2018 berdasarkan metode Market Value Added (MVA) ?

3. Kinerja Keuangan dengan menggunakan Economic Value Added (EVA), dan Market Value Added (MVA) dengan Time Series Approach di Industri Semen yang listing di Bursa Efek Indonesia Tahun 2013-2018 ?

\section{B. LANDASAN TEORI}

\section{Kinerja Keuangan}

Berdasarkan Keputusan Menteri Keuangan Republik Indonesia No. 740/ KMK.00/1989 tentang Peningkatan Efisiensi dan Produktivitas Badan Usaha Milik Negara Kinerja keuangan adalah prestasi yang dicapai oleh perusahaan dalam periode tertentu yang mencerminkan tingkat kesehatan perusahaan tersebut. Kinerja keuangan 
perusahaan merupakan salah satu dasar penilaian mengenai kondisi-kondisi keuangan yang dapat dilakukan berdasarkan analisis rasio- rasio keuangan.

Kinerja dapat diartikan sebagai prestasi yang dicapai perusahaan dalam suatu periode tertentu yang mencerminkan tingkat kesehatan perusahaan tersebut (Winarni dan Sugiyarso, 2005:111). Kinerja keuangan merupakan suatu analisa dalam periode waktu tertentu untuk mengukur keberhasilan suatu organisasi atau perusahaan dalam menghasilkan laba dengan menggunakan aturan pelaksanaan keuangan secara baik dan benar dengan cara menganalisis dan mengevaluasi laporan keuangan perusahaan dengan tujuan bisa memberi masukan manajer perusahaan atau investor dalam menetukan kebijakan perusahaan .

\section{Economic Value Added (EVA)}

Economic Value Added senbagai tolak ukur kinerja keuangan dengan mengukur perbedaan antara pengembalian atas modal perusahaan dengan biaya modal (Young dan O'Byrne). Menurut Keown, dkk. rumus EVA adalah

$$
\text { EVA }=\text { NOPAT }-(\text { WACC } \times \text { IC) }
$$

\section{Langkah Perhitungan Economic Value Added (EVA)}

\begin{tabular}{|l|l|}
\hline \multicolumn{1}{|c|}{ Komponen EVA } & \multicolumn{1}{c|}{ Rumus } \\
\hline NOPAT & Pendapatan Usaha Bersih $(1-$ Tarif Pajak $)$ \\
\hline WACC & {$[($ D xrd $)(1$-tax $)+($ E $\times$ re $)]$} \\
\hline IC & (Total Hutang + Ekuitas $)-$ Hutang Jangka Pendek \\
\hline EVA & NOPAT $-($ WACC $\times$ IC $)$ \\
\hline
\end{tabular}

Keterangan:

NOPAT : Net Operating Profit After Tax (Laba operasi bersih setelah pajak)

WACC : Weighted Average Cost of Capital (Biaya modal rata - rata tertimbang)

D : Biaya modal hutang

rd : Persentase hutang dalam struktur modal Tax : Pajak

E : Biaya modal ekuitas

re : Persentase biaya modal pada struktur modal

IC : Invested Capital

EVA : Economic Value Added

EVA > 0 maka menunjukkan telah terjadi proses nilai tambah pada perusahaan dan berhasil menciptakan nilai bagi penyedia dana. Tingkat pengembalian yang dihasilkan lebih besar daripada tingkat biaya modal atau tingkat biaya yang diharapkan investor atas investasi yang dilakukannya. EVA $=0$ menunjukkan posisi impas perusahaan karena semua laba digunakan untuk membayar kewajiban kepada penyedia dana baik kreditor maupun pemegang saham. EVA $<0$ menunjukkan tidak terjadinya proses nilai tambah karena laba yang tersedia tidak dapat memenuhi harapan para investor. Nilai perusahaan berkurang akibat tingkat pengembalian yang dihasilkan lebih rendah dari tingkat pengembalian yang diharapkan penyedia dana (investor) .

\section{Market Value Added (MVA)}

Menurut Keown dkk. Market Value Added (MVA) dapat diartikan sebagai perbedaan nilai pasar antara perusahaan dan modal yang telah diinvestasikan. MVA dapat dihitung sebagai berikut :

$$
\text { MVA = Nilai perusahaan }- \text { Modal yang diinvestasikan }
$$




\begin{tabular}{|l|l|}
\hline \multicolumn{1}{|c|}{ Komponen MVA } & \multicolumn{1}{c|}{ Rumus } \\
\hline NOPAT & Pendapatan Usaha Bersih $(1-$ Tarif Pajak $)$ \\
\hline WACC & {$[($ D xrd $)(1$-tax $)+($ E $\times$ re $)]$} \\
\hline IC & (Total Hutang + Ekuitas $)-$ Hutang Jangka Pendek \\
\hline EVA & NOPAT $-($ WACC $\times$ IC $)$ \\
\hline
\end{tabular}

Keterangan:

NOPAT : Net Operating Profit After Tax (Laba operasi bersih setelah pajak)

WACC : Weighted Average Cost of Capital (Biaya modal rata - rata tertimbang)

D : Biaya modal hutang

rd : Persentase hutang dalam struktur modal Tax : Pajak

E : Biaya modal ekuitas

re : Persentase biaya modal pada struktur modal

IC : Invested Capital

EVA : Economic Value Added

Jika MVA positif, berarti pihak manajemen perusahaan telah mampu meningkatkan kekayaan perusahaan dan para pemegang saham atau bisa dikatakan kinerja perusahaan tersebut baik. MVA negatif, berarti pihak manajemen tidak mampu atau telah menurunkan kekayaan perusahaan dan kekayaan para pemegang saham, atau bisa dikatakan bahwa kinerja perusahaan tidak baik .

\section{METODOLOGI PENELITIAN}

Penelitian ini menggunakan pendekatan kuantitatif dari data laporan keuangan Industri Semen yang terdaftar di Bursa Efek Indonesia (BEI) pada periode 2013-2018 .

\section{Objek Penelitian sebagai berikut :}

\begin{tabular}{cll} 
No. & Kode & Industri Semen di Indonesia \\
\hline 1 & INTP & PT. Indocement Tunggal Prakarsa Tbk. \\
2 & SMBR & PT. Semen Baturaja (Persero) Tbk. \\
3 & SMCB & PT. Holcim Indonesia Tbk. \\
4 & SMGR & PT. Semen Indonesia (Persero) Tbk. \\
\hline
\end{tabular}

Metode analisis data secara kuantitatif denga berdasarkan data sekunder dari laporan keuangan yang telah dikumpulkan. mengolah data dengan data keuangan yang diperoleh kemudian di analisa .

Tahapan sebagai berikut :

1. Mencari data yang diperlukan dari laporan keuangan tahunan dari industry semen periode 2013 sampai 2018

2. Menghitung dan menganalisa Economic Value Added (EVA)

4. Menghitung dan menganalisa Market Value Added (MVA)

5. Membuat kesimpulan dari hasil analisa data. 


\section{HASIL DAN PEMBAHASAN}

1. Penilaian Kinerja Keuangan Economic Value Added (EVA) dan Market Value Added (MVA) PT. Indocement Tunggal Prakarsa Tbk.

Penilaian Kinerja Keuangan PT. Indocement Tunggal Prakarsa Tbk. adalah sbb :

Tabel 1 : Analisa Kinerja Keuangan PT. Indocement Tunggal Prakarsa Tbk. Periode 2013-2018 (dalam milyaran rupiah)

\begin{tabular}{|l|c|c|c|c|c|c|c|c|}
\hline \multirow{2}{*}{ Variabel } & \multicolumn{6}{|c|}{ Periode } & Rata- & \multirow{2}{*}{ Kinerja } \\
\cline { 2 - 9 } & $\mathbf{2 0 1 3}$ & $\mathbf{2 0 1 4}$ & $\mathbf{2 0 1 5}$ & $\mathbf{2 0 1 6}$ & $\mathbf{2 0 1 7}$ & $\mathbf{2 0 1 8}$ & 336 & Baik \\
\hline $\begin{array}{l}\text { Economic Value Added } \\
(\text { EVA) }\end{array}$ & 516 & 537 & 359 & 361 & 172 & 68 & 336 & \\
\hline $\begin{array}{l}\text { Market Value Added } \\
(\text { MVA })\end{array}$ & 49,76 & 66,41 & 57,23 & 29,73 & 55,42 & 44,06 & 50,43 & Baik \\
\hline
\end{tabular}

Sumber: Data Diolah, 2020

Dari hasil perhitungan tabel 1 rekapitulasi kinerja Keuangan perusahaan diatas menunjukan Economic Value Added (EVA) menunjukkan kondisi kinerja keuangan perusahaan berkinerja baik dikarenakan nilai rata-rata EVA sebesar 336 diatas ratarata industri -181 artinya kinerja keuangan PT. Indocement Tunggal Prakarsa Tbk. dilihat dari EVA berkinerja baik,dan Market Value Added (MVA) menunjukkan kondisi kinerja keuangan perusahaan berkinerja baik dikarenakan nilai rata-rata MVA sebesar 50,43 diatas rata-rata industri 24,52 artinya kinerja keuangan PT. Indocement Tunggal Prakarsa Tbk. dilihat dari MVA berkinerja baik .

2. Penilaian Kinerja Keuangan Economic Value Added (EVA) dan Market Value Added (MVA) PT. Semen Baturaja (Persero) Tbk.

Penilaian Kinerja Keuangan PT. Semen Baturaja (Persero) Tbk.adalah sbb :

Tabel 2 : Analisa Kinerja Keuangan PT. Semen Baturaja (Persero) Tbk.. Periode 20132018 (dalam milyaran rupiah)

\begin{tabular}{|c|c|c|c|c|c|c|c|c|}
\hline \multirow{2}{*}{ Variabel } & \multicolumn{6}{|c|}{ Periode } & \multirow{2}{*}{$\begin{array}{l}\text { Rata- } \\
\text { rata }\end{array}$} & \multirow{2}{*}{ Kinerja } \\
\hline & 2013 & 2014 & 2015 & 2016 & 2017 & 2018 & & \\
\hline $\begin{array}{l}\text { Economic Value Added } \\
(E V A)\end{array}$ & 22 & 19 & 27 & 11 & 19 & -71 & 5 & Baik \\
\hline $\begin{array}{l}\text { Market Value Added } \\
\text { (MVA) }\end{array}$ & 729 & 1,00 & -150 & 23,37 & 33,32 & 12,48 & 11,79 & $\begin{array}{l}\text { Tidak } \\
\text { Baik }\end{array}$ \\
\hline
\end{tabular}

Dari hasil perhitungan tabel 2 rekapitulasi kinerja Keuangan perusahaan diatas menunjukan Economic Value Added (EVA) menunjukkan kondisi kinerja keuangan perusahaan berkinerja baik dikarenakan nilai rata-rata EVA sebesar 5 diatas rata-rata industri -181 artinya kinerja keuangan PT. Semen Baturaja (Persero) Tbk.dilihat dari EVA berkinerja baik,dan Market Value Added (MVA) menunjukkan kondisi kinerja keuangan perusahaan berkinerja tidak baik dikarenakan nilai rata-rata MVA sebesar 11,79 dibawah rata-rata industri 24,52 artinya kinerja keuangan PT. Semen Baturaja (Persero) Tbk. dilihat dari MVA berkinerja tidak baik .

3. Penilaian Kinerja Keuangan Economic Value Added (EVA) dan Market Value Added (MVA) PT. Holcim Indonesia Tbk.

Penilaian Kinerja Keuangan PT. Holcim Indonesia Tbk. adalah sbb : 
Tabel 3 : Analisa Kinerja Keuangan PT. Holcim Indonesia Tbk. Periode 2013-2018 (dalam milyaran rupiah)

\begin{tabular}{|l|c|c|c|c|c|c|l|l|}
\hline \multirow{2}{*}{ Variabel } & \multicolumn{6}{|c|}{ Periode } & $\begin{array}{l}\text { Rata- } \\
\text { rata }\end{array}$ & Kinerja \\
\cline { 2 - 9 } & $\mathbf{2 0 1 3}$ & $\mathbf{2 0 1 4}$ & $\mathbf{2 0 1 5}$ & $\mathbf{2 0 1 6}$ & $\mathbf{2 0 1 7}$ & $\mathbf{2 0 1 8}$ & $-1,05$ & $\begin{array}{l}\text { Tidak } \\
\text { Baik }\end{array}$ \\
\hline $\begin{array}{l}\text { Economic Value Added } \\
(\text { EVA })\end{array}$ & -412 & -126 & -407 & $-1,03$ & $-1,83$ & $-2,49$ & $-1,41$ & $\begin{array}{l}\text { Tidak } \\
\text { Baik }\end{array}$ \\
\hline $\begin{array}{l}\text { Market Value Added } \\
(M V A)\end{array}$ & 5,80 & 3,36 & $-5,74$ & $-7,55$ & $-9,84$ & 5,52 & $-1,41$ \\
\hline
\end{tabular}

Sumber: Data Diolah, 2020

Dari hasil perhitungan tabel 3 rekapitulasi kinerja Keuangan perusahaan diatas menunjukan Economic Value Added (EVA) menunjukkan kondisi kinerja keuangan perusahaan berkinerja tidak baik dikarenakan nilai rata-rata EVA sebesar -1,05 dibawah rata-rata industri -181 artinya kinerja keuangan PT. Holcim Indonesia Tbk. dilihat dari EVA berkinerja tidak baik dan Market Value Added (MVA) menunjukkan kondisi kinerja keuangan perusahaan berkinerja tidak baik dikarenakan nilai rata-rata MVA sebesar -1,41 dibawah rata-rata industri 24,52 artinya kinerja keuangan PT. Holcim Indonesia Tbk. dilihat dari MVA berkinerja tidak baik .

4. Penilaian Kinerja Keuangan Economic Value Added (EVA) dan Market Value Added (MVA) PT. Semen Indonesia (Persero) Tbk.

Penilaian Kinerja Keuangan PT. Semen Indonesia (Persero) Tbk.adalah sbb :

Tabel 4 : Analisa Kinerja Keuangan PT. Semen Indonesia (Persero) Tbk. Periode 2013-2018 (dalam milyaran rupiah)

\begin{tabular}{|c|c|c|c|c|c|c|c|c|}
\hline \multirow{2}{*}{ Variabel } & \multicolumn{6}{|c|}{ Periode } & \multirow{2}{*}{$\begin{array}{l}\text { Rata- } \\
\text { rata }\end{array}$} & \multirow{2}{*}{ Kinerja } \\
\hline & 2013 & 2014 & 2015 & 2016 & 2017 & 2018 & & \\
\hline $\begin{array}{l}\text { Economic Value Added } \\
\text { (EVA) }\end{array}$ & 391 & 269 & 166 & 180 & -512 & -597 & -17 & Baik \\
\hline $\begin{array}{l}\text { Market Value Added } \\
\text { (MVA) }\end{array}$ & 58,44 & 67,05 & 36,06 & 18,35 & 18,56 & 25,26 & 37,29 & Baik \\
\hline
\end{tabular}

Sumber: Data Diolah, 2020

Dari hasil perhitungan tabel 4 rekapitulasi kinerja Keuangan perusahaan diatas menunjukan Economic Value Added (EVA) menunjukkan kondisi kinerja keuangan perusahaan berkinerja baik dikarenakan nilai rata-rata EVA sebesar -17 diatas ratarata industri -181 artinya kinerja keuangan PT. Semen Indonesia (Persero) Tbk. dilihat dari EVA berkinerja baik,dan Market Value Added (MVA) menunjukkan kondisi kinerja keuangan perusahaan berkinerja baik dikarenakan nilai rata-rata MVA sebesar 37,29 diatas rata-rata industri 24,52 artinya kinerja keuangan PT. Semen Indonesia (Persero) Tbk. dilihat dari MVA berkinerja baik .

\section{Penilaian Economic Value Added (EVA) Pedekatan Time Series Approach Industri Semen di Indonesia}

Time Series Approach sebuah pendekatan untuk mengetahui kondisi masingmasing perusahaan dan variabel dari waktu ke waktu pada priode tertentu dari penilaian data keuangan secara Time Series pada Industri Semen di Indonesia.

Kinerja Keuangan Economic Value Added (EVA) Industri Semen di Indonesia dengan pendekatan data secara Time Series sebagai berikut :

Tabel 5 : Penilaian Economic Value Added (EVA) Industri Semen di Indonesia Periode 2013-2018 (dalam milyaran rupiah)

\begin{tabular}{|l|c|c|c|c|c|c|c|c|}
\hline \multirow{2}{*}{$\begin{array}{c}\text { Industri Semen } \\
\text { di Indonesia }\end{array}$} & \multicolumn{6}{|c|}{ Economic Value Added (EVA) } & Rata- & \multirow{2}{*}{ Kinerja } \\
\cline { 2 - 10 } & $\mathbf{2 0 1 3}$ & $\mathbf{2 0 1 4}$ & $\mathbf{2 0 1 5}$ & $\mathbf{2 0 1 6}$ & $\mathbf{2 0 1 7}$ & $\mathbf{2 0 1 8}$ & $\mathbf{3}$ & \\
\hline $\begin{array}{l}\text { PT. Indocement Tunggal } \\
\text { Prakarsa Tbk. }\end{array}$ & 516 & 537 & 359 & 361 & 172 & 68 & 336 & Baik \\
\hline "PT. Semen Baturaja & 22 & 19 & 27 & 11 & 19 & - & 5 & Baik \\
\hline
\end{tabular}




\begin{tabular}{|c|c|c|c|c|c|c|c|c|}
\hline (Persero) Tbk. & & & & & & 71 & & \\
\hline $\begin{array}{l}\text { PT. Holcim Indonesia } \\
\text { Tbk. }\end{array}$ & $\begin{array}{c}- \\
412\end{array}$ & $\begin{array}{c}- \\
126\end{array}$ & $\begin{array}{c}- \\
407\end{array}$ & $\begin{array}{c}- \\
1,03\end{array}$ & $\overline{1} \overline{8}$ & $\begin{array}{c}- \\
2,49\end{array}$ & $\begin{array}{c}- \\
1,05\end{array}$ & $\begin{array}{c}\text { Tidak } \\
\text { Baik }\end{array}$ \\
\hline $\begin{array}{l}\text { PT. Semen Indonesia } \\
\text { (Persero) Tbk. }\end{array}$ & 391 & 269 & 166 & 180 & 5 & $\begin{array}{c}- \\
597\end{array}$ & $\begin{array}{c}- \\
17 \\
\end{array}$ & Baik \\
\hline Standar Industri & 129 & 175 & 36 & $\begin{array}{c}- \\
119\end{array}$ & $\overline{538}$ & $\begin{array}{c}- \\
772\end{array}$ & $\begin{array}{c} \\
181\end{array}$ & $\begin{array}{c}\text { Tidak } \\
\text { Baik }\end{array}$ \\
\hline
\end{tabular}

Grafik 1 : Economic Value Added (EVA) Industri Semen di Indonesia

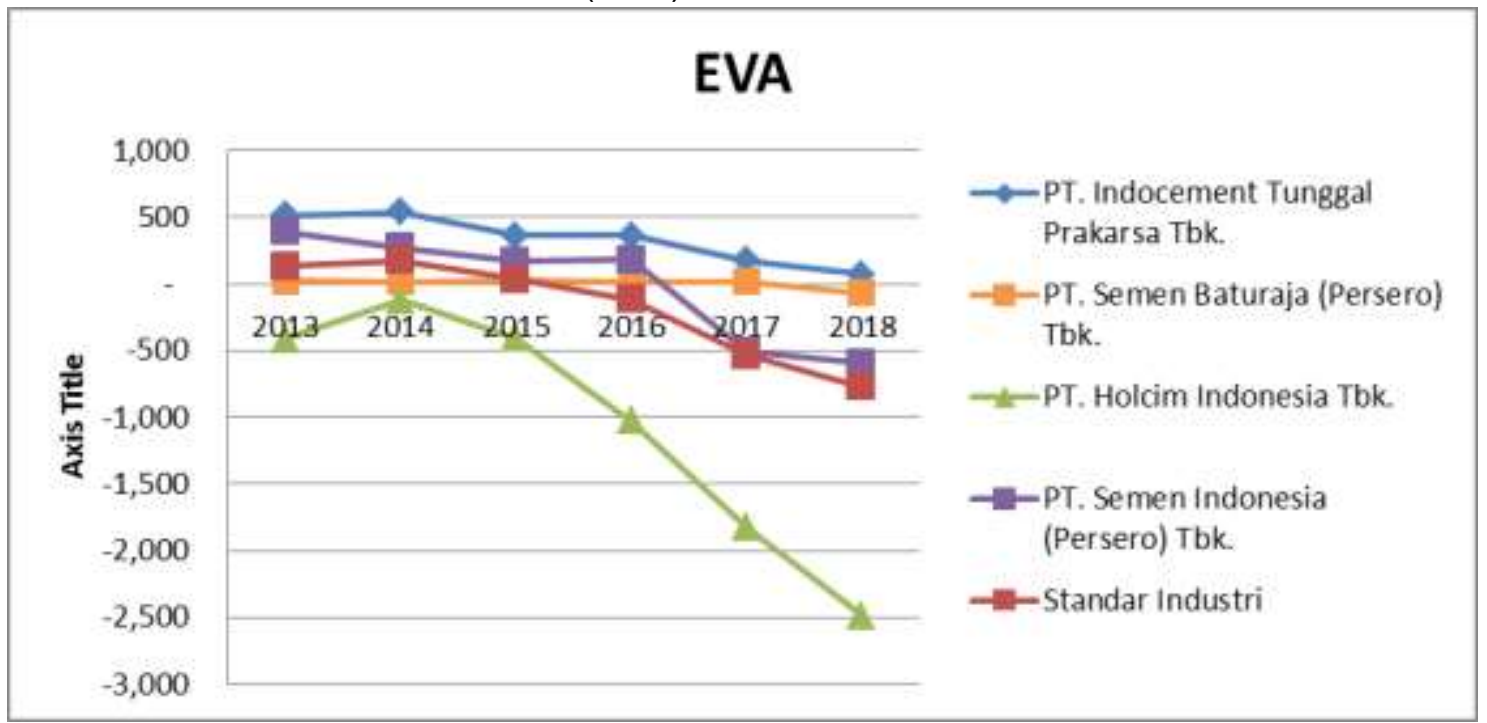

Dari hasil perhitungan Economic Value Added (EVA) pada Tabel 5, nilai rata-rata EVA perusahaan PT. Holcim Indonesia Tbk.. hasilnya negatif dan di bawah nilai rata rata industri sebesar -181 berarti perusahaan tidak mampu memberikan nilai tambah bagi para pemegang sahamnya karena nilai EVA bernilai negatif $(E V A<0)$ sehingga dikatakan berkinerja tidak baik. sedangkan Nilai rata-rata EVA pada PT. Indocement Tunggal Prakarsa Tbk., PT. Semen Baturaja (Persero) Tbk. dan PT. Semen Indonesia (Persero) Tbk. adalan positif atau di atas rata rata industri sebesar -181 berarti perusahaan mampu memberikan nilai tambah bagi para pemegang sahamnya karena nilai EVA bernilai positif (EVA > 0) sehingga dikatakan berkinerja baik .

Economic Value Added (EVA) rata-rata industri Semen di Indonesia periode 2013-2018 mengalami fluktuatif. Periode 2014 sd 2018 mengalami penurunan dari 175 tahun 2014 menjadi -772 pada tahun 2018 ini berarti secara trend terjadi penurunan. Hal ini disebabkan adanya peningkatan biaya modal dan menunjukkan bahwa perusahaan tidak dapat memberikan kembalian investasi sesuai dengan harapan ipemegang saham dan investor, hanya kenaikan dari 2013 ke 2014 dari 129 ke 175. dari tabel diatas terlihat rata-rata industri sebesar -181 hal ini mengindikasikan bahwa perusahaan tidak mampu memberikan nilai tambah bagi para pemegang sahamnya karena nilai EVA bernilai negatif $(E V A<0)$ sehingga dikatakan berkinerja tidak baik .

\section{Penilaian Market Value Added (MVA) Pendekatan Time Series Approach Industri Semen di Indonesia}

Kinerja Keuangan Market Value Added (MVA) Industri Semen di Indonesia dengan pendekatan data secara Time Series sebagai berikut : 
Tabel 6 : Penilaian Market Value Added (MVA) Industri Semen di Indonesia Periode 2013-2018 (dalam milyaran rupiah)

\begin{tabular}{|c|c|c|c|c|c|c|c|c|}
\hline \multirow{2}{*}{$\begin{array}{l}\text { Industri Semen } \\
\text { di Indonesia }\end{array}$} & \multicolumn{6}{|c|}{ Market Value Added (MVA) } & \multirow{2}{*}{$\begin{array}{l}\text { Rata- } \\
\text { rata }\end{array}$} & \multirow{2}{*}{ Kinerja } \\
\hline & 2013 & 2014 & 2015 & 2016 & 2017 & 2018 & & \\
\hline $\begin{array}{l}\text { PT. Indocement Tunggal } \\
\text { Prakarsa Tbk. }\end{array}$ & 49,76 & 66,41 & 57,23 & 29,73 & 55,42 & 44,06 & 50,43 & Baik \\
\hline $\begin{array}{l}\text { PT. Semen Baturaja } \\
\text { (Persero) Tbk. }\end{array}$ & 729 & 1,00 & -150 & 23,37 & 33,32 & 12,48 & 11,79 & $\begin{array}{l}\text { Tidak } \\
\text { Baik }\end{array}$ \\
\hline $\begin{array}{l}\text { PT. Holcim Indonesia } \\
\text { Tbk. }\end{array}$ & 5,80 & 3,36 & $-5,74$ & $-7,55$ & $-9,84$ & 5,52 & $-1,41$ & Tidak \\
\hline $\begin{array}{l}\text { PT. Semen Indonesia } \\
\text { (Persero) Tbk. }\end{array}$ & 58,44 & 67,05 & 36,06 & 18,35 & 18,56 & 25,26 & 37,29 & Baik \\
\hline Standar Industri & 28,68 & 34,45 & 21,85 & 15,97 & 24,36 & 21,83 & 24,52 & Baik \\
\hline
\end{tabular}

Grafik 2 : Market Value Added (MVA) Industri Semen di Indonesia

Sumber: Data Diolah, 2020

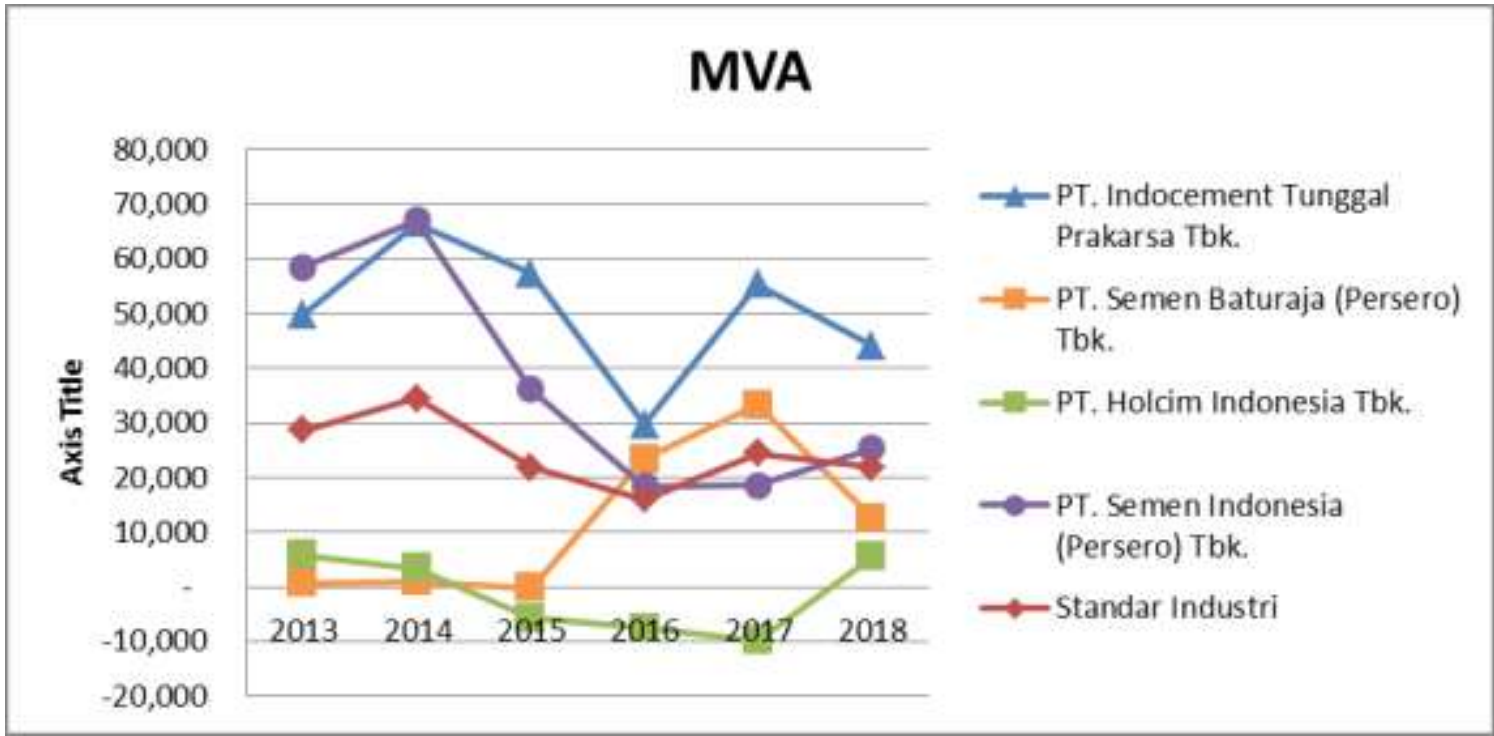

Dari hasil perhitungan Market Value Added (MVA) pada Tabel 6, nilai rata-rata MVA perusahaan PT. Semen Baturaja (Persero) Tbk. dan PT. Holcim Indonesia Tbk. hasilnya negatif dan di bawah nilai rata rata industri sebesar 24,52 berarti perusahaan tidak mampu memberikan nilai tambah bagi para pemegang sahamnya karena nilai EVA bernilai negatif (MVA < 0) sehingga dikatakan berkinerja tidak baik. sedangkan Nilai rata-rata MVA pada PT. Indocement Tunggal Prakarsa Tbk. dan PT. Semen Indonesia (Persero) Tbk . adalan positif atau di atas rata rata industri sebesar 24,52 berarti perusahaan mampu memberikan nilai tambah bagi para pemegang sahamnya karena nilai MVA bernilai positif (MVA > 0) sehingga dikatakan berkinerja baik .

Market Value Added (MVA) rata-rata industri Semen di Indonesia periode 20132018 mengalami fluktuatif. Periode 2014 sd 2016 mengalami penurunan dari 34,45 tahun 2014 menjadi 15,97 pada tahun 2016 ini berarti secara trend terjadi penurunan. Hal ini disebabkan adanya peningkatan biaya modal dan menunjukkan bahwa perusahaan tidak dapat memberikan kembalian investasi sesuai dengan harapan ipemegang saham dan investor, hanya kenaikan dari 2013 ke 2014 dari 28,68 ke 34,45 dan kenaikan dari 2016 ke 2018 dari 15,97 ke 21,83. dari tabel diatas terlihat rata-rata industri sebesar 24,52 hal ini mengindikasikan bahwa perusahaan mampu memberikan nilai tambah bagi para pemegang sahamnya karena nilai MVA bernilai positif $(M V A<0)$ sehingga dikatakan berkinerja baik . 


\section{Penilaian Kinerja Keuangan pada Industri Semen di Indonesia yang Listing di Bursa Efek Indonesia Tahun 2013-2018 berdasarkan Economic Value Added (EVA) dan Market Value Added (MVA)}

Berdasarkan penilaian Economic Value Added (EVA) dan Market Value Added (MVA) pada Industri Semen di Indonesia adalah sbb :

Tabel 7 : Analisis Economic Value Added (EVA) dan Market Value Added (MVA) Perusahaan pada Industri Semen di Indonesia

\begin{tabular}{|c|c|c|c|c|c|c|c|}
\hline \multirow{2}{*}{ Variabel } & \multicolumn{4}{|c|}{ Kode Perusahaan } & $\begin{array}{c}\text { Rata- } \\
\text { Rata } \\
\text { Industri }\end{array}$ & Sat & $\begin{array}{c}\text { Kinerja } \\
\text { Industri }\end{array}$ \\
\cline { 2 - 8 } & INTP & SMBR & SMCB & SMGR & & & $\begin{array}{c}\text { Tidak } \\
\text { Baik }\end{array}$ \\
\hline $\begin{array}{c}\text { Economic Value Added } \\
(E V A)\end{array}$ & 336 & 5 & $-1,049$ & -17 & -181 & Rp \\
\hline $\begin{array}{c}\text { Market Value Added } \\
(\text { MVA })\end{array}$ & 50,43 & 11,79 & $-1,41$ & 37,29 & 24,52 & Rp & Baik \\
\hline RATA-RATA & $\mathbf{2 5 , 3 8}$ & $\mathbf{5 , 9 0}$ & $\mathbf{- 1 , 2 3}$ & $\mathbf{1 8 , 6 3}$ & $\mathbf{1 2 , 1 7}$ & Rp & Baik \\
\hline
\end{tabular}

Sumber: Data diolah 2020

Setelah dilakukan perhitungan terhadap masing-masing variabel dari empat tahun berturut-turut sehingga dapat diketahui rata-rata penilaian Analisis Economic Value Added (EVA) dan Market Value Added (MVA) pada Industri Semen di Indonesia yang Listing di Bursa Efek Indonesia Tahun 2013-2018 sebesar 12,17 menunjukan hasill positif, Hal ini menunujukkan bahwa kondisi Industri Semen di Indonesia secara keseluruhan dikatakan berkinerja BAIK .

\section{E. KESIMPULAN}

\section{Kesimpulan}

Berdasarkan Analisis "Economic Value Added (EVA), Financial Value Added (FVA) dan Market Value Added (MVA) dengan Time Series Approach (TSA) perusahaan Konstruksi (BUMN) di Indonesia yang Listing di Bursa Efek Indonesia Tahun 2013-2017" sebagai berikut :

1. Penilaian Kinerja Keuangan Industri Semen yang listing di Bursa Efek Indonesia Tahun 2013-2018 berdasarkan Economic Value Added (EVA), nilai rata-rata EVA perusahaan PT. Holcim Indonesia Tbk.. hasilnya negatif dan di bawah nilai rata rata industri sebesar -181 berarti perusahaan tidak mampu memberikan nilai tambah bagi para pemegang sahamnya karena nilai EVA bernilai negatif $(E V A<0)$ sehingga dikatakan berkinerja tidak baik. sedangkan Nilai rata-rata EVA pada PT. Indocement Tunggal Prakarsa Tbk., PT. Semen Baturaja (Persero) Tbk. dan PT. Semen Indonesia (Persero) Tbk. adalan positif atau di atas rata rata industri sebesar -181 berarti perusahaan mampu memberikan nilai tambah bagi para pemegang sahamnya karena nilai EVA bernilai positif (EVA > 0) sehingga dikatakan berkinerja baik

2. Penilaian Kinerja Keuangan Industri Semen yang listing di Bursa Efek Indonesia Tahun 2013-2018 berdasarkan metode Market Value Added (MVA), nilai rata-rata MVA perusahaan PT. Semen Baturaja (Persero) Tbk. dan PT. Holcim Indonesia Tbk. hasilnya negatif dan di bawah nilai rata rata industri sebesar 24,52 berarti perusahaan tidak mampu memberikan nilai tambah bagi para pemegang sahamnya karena nilai EVA bernilai negatif $(\mathrm{MVA}<0)$ sehingga dikatakan berkinerja tidak baik. sedangkan Nilai rata-rata MVA pada PT. Indocement Tunggal Prakarsa Tbk. dan PT. Semen Indonesia (Persero) Tbk . adalan positif atau di atas rata rata industri sebesar -24,52 berarti perusahaan mampu memberikan nilai tambah bagi para pemegang sahamnya karena nilai MVA bernilai positif $(M V A>0)$ sehingga dikatakan berkinerja baik . 
3. Kinerja Keuangan dengan menggunakan Economic Value Added (EVA), dan Market Value Added (MVA) dengan Time Series Approach di Industri Semen yang listing di Bursa Efek Indonesia Tahun 2013-2018, rata-rata penilaian Analisis Economic Value Added (EVA) dan Market Value Added (MVA) pada Industri Semen di Indonesia yang Listing di Bursa Efek Indonesia Tahun 2013-2018 sebesar 12,17 menunjukan hasill positif, Hal ini menunujukkan bahwa kondisi Industri Semen di Indonesia secara keseluruhan dikatakan berkinerja BAIK

\section{DAFTAR PUSTAKA}

.Anesti Iswandira (2015), Analisis economic value added (EVA) dan market value added (MVA) sebagai alat untuk mengukur kinerja keuangan perusahaan pt.indofood sukses makmur tbk., Jurnal IImiah Inovator, Edisi Maret 2015,

Abdul Kadim, K., \& Nardi, S. (2018). Eviews Analysis: Determinant Of Leverage And Company's Performance. Global and Stochastic Analysis (GSA), 5(7), 249-260.

Anggoro Dwi Putra, 2014 Economic Value Added (EVA) dan Market Value Added (MVA) sebagai Alat Ukur Kinerja Keuangan (Studi Pada PT. HM Sampoerna, Tbk dan PT. Gudang Garam, Tbk Periode 2011-2013), Fakultas Ekonomi \& Bisnis, ABFI Institute Perbanas Jakarta

Anthony, Robert N. dan Govindarajan, Vijay. (2012). Management Control System. Terjemahan Kurniawan Tjakrawala. Jakarta: Penerbit Salemba Empat.

Artinah, Budi. 2011. - Pengaruh Intellectual Capital terhadap Profitabilitas (Studi Empiris pada Perusahaan Perbankan. Jurnal Socioscientia Kopertis Wilayah XI Kalimantan. Vol. 3 (1): hal. 51-58.

Bank Indonesia. (2012). Laporan Pengawasan Perbankan 2011, (Online), (http://www.bi.go.id, diaskes 10 Maret 2015).

Brigham \& Houston. (2010) Dasar - Dasar Manajemen Keuangan (Essentials Of Financial Management). Edisi ke - 11. Salemba Empat. Jakarta. (Diterjemahkan oleh Ali Akbar Yulianto).

Fraser, Lyn. M dan Ormiston, Aileen. (2008). Memahami Laporan Keuangan. Edisi ketujuh. Diterjemahkan oleh Priyo Darmawan. Jakarta:PT. Indeks

Ghozali, Imam, (2007). Aplikasi Analisis Multivariate dengan Program SPPS. Semarang: Badan Penerbit UNDIP.

Gujarati, Damodar N .(2003), Basic Econometrics, McGraw-Hill, 4Th ed. New York

Hanafi. 2004. Manajemen Keuangan. Yogyakarta: BPFE UGM.

Husnan, S (2015). Teori Porto folio dan Analisis Investasi edisi Keempat. Yogyakarta: BPFE

Husnan, Suad. Manajemen Keuangan (2008): Teori dan Penerapan Buku 1, Edisi 4, BPFE Yogyakarta

Ikatan Akuntan Indonesia. (2010). Pernyataan Standar Akuntansi Keuangan No. 19, Per 7 Maret 2016.

Indriantoro, N. \& Supomo, B. (2002). Metodologi Penelitian Bisnis untuk Akuntansi dan Manajemen. Yogyakarta: BPFE.

Kadim, A., \& Sunardi, N. (2020). Penilaian Kinerja Keuangan dengan metode Economic Value Added (EVA), Financial Value Added (FVA) dan Market Value Added (MVA)(Studi Pada Industri Telekomunikasi di Indonesia yang Terdaftar di BEI Tahun 2014-2018). Jurnal SEKURITAS (Saham, Ekonomi, Keuangan dan Investasi), 3(2), $56-65$.

Kasmir. (2012). Bank dan Lembaga Keuangan Lainnya. PT Raja Grafindo Persada

Kasmir. (2014). Analisis Laporan Keuangan. Jakarta:PT. Raja Grafindo Persada.

M. Ridho Firdausi, Dadan R.,\& AS. Dewi 2017 Analisis kinerja keuangan dengan menggunakan metode economic value added (EVA), financial value added (FVA) dan market value added (MVA), e-Proceeding of Management : Vol.4, No.2 Agustus 2017 | Page 1413. 
Mamik Mardiani (2012). Penilaian Kinerja Keuangan Perusahaan Menggunakan Analisis Rasio Keuangan dan Konsep Eva (Economic Value Added) Studi Pada PT HM Sampoerna, Tbk. yang Terdaftar di BEl Periode Tahun 2009-2011, Fakultas IImu Administrasi, Universitas Brawijaya

Mursalim, (2009) Economic Value Added dan Market Value Added Dampaknya Terhadap Nilai Perusahaan, Jurnal Keuangan dan Perbankan, Vol. 13, No.3 September 2009, hal. $498-505$

Otoritas Jasa Keuangan, (2015), Roadmap Perbankan Syariah Indonesia 2015-2019, Departemen Perbankan Syariah OJK, Jakarta Pangestika,

Rose, Peter S and Sylvia C Hudgins (2010) Bank Management and Financial Services. New York : Mc Grow Hill

Styfanda, (2015), Analisis Estimasi Moel Regresi Data Panel Dengan Pendekatan Common Effect Model (CEM), Fixed Effect Model (FEM), dan Random Effect Model (REM), Skripsi Fakultas MIPA Universitas Negeri Semarang, tidak dipublikasikan

Sunardi, N. (2017). Determinan Kebijakan Utang Serta Implikasinya terhadap Kinerja Perusahaan (Perusahaan yang tergabung dalam indeks LQ. 45 yang terdaftar di Bursa Efek Indonesia Tahun 2011-2015). Jurnal Sekuritas, 1(1).

Sunardi, N. (2018). Analisis Du Pont System Dengan Time Series Approach (Tsa) Dan Cross Sectional Approach (Csa) Dalam Penilaian Kinerja Keuangan Perusahaan (Studi Pada Industri Konstruksi (BUMN) di Indonesia Yang Listing di BEI Tahun 2013-2017). Jurnal SEKURITAS (Saham, Ekonomi, Keuangan dan Investasi), 1(4).

Sunardi, N. (2018). Analisis Economic Value Added (Eva), Financial Value Added (FVA) Dan Market Value Added (MVA) Dengan Time Series Approach Sebagai Alat Penilaian Kinerja Keuangan (Studi Pada Industri Konstruksi (BUMN) di Indonesia Yang Listing di BEI Tahun 2013-2017). Jurnal SEKURITAS (Saham, Ekonomi, Keuangan dan Investasi), 2(1).

Sunardi, N. (2018). Kinerja Perusahan Pendekatan Du Pont System Terhadap Harga Dan Return Saham (Perusahaan yang tergabung dalam Industri Real Estate dan Properti yang terdaftar di Bursa Efek Indonesia Tahun 2011-2017). JIMF (Jurnal IImiah Manajemen Forkamma), 1(3).

Sunardi, N. (2018). Kinerja Perusahan Pendekatan Du Pont System Terhadap Harga dan Return Saham (Perusahaan yang tergabung dalam Industri Real Estate dan Properti yang terdaftar di Bursa Efek Indonesia Tahun 2011-2017). JIMF (Jurnal IImiah Manajemen Forkamma), 1(3).

Sunardi, N., \& Sasmita, A. S. (2019). Pengaruh Likuiditas, Leverage Dan Growth Terhadap Kinerja Industri Makanan Dan Minuman Yang Tercatat Di Indonesia Stock Exchange Selama Periode Tahun 2011-2015. Jurnal Sekuritas (Saham, Ekonomi, Keuangan dan Investasi), 2(2), 81-97.

Taswan. 2010. Manajemen Perbankan, Konsep, Teknik, dan Aplikasi. Edisi Kedua. Yogyakarta : UPP STIM YKPN.

Usman, Bahtiar. 2003. Analisis Rasio Keuangan dalam Memprediksi Perubahan Laba pada Bank-Bank di Indonesia. Media Riset \& Manajemen. Vol.3 (1)

Vandi Surya Winata (2016), Penggunaan Analisis Kinerja Keuangan Perusahaan Dengan Pendekatan Economic Value Added (Eva) Dan Market Value Added (Mva) Pada Perusahaan Manufaktur Yang Go Public Di Bursa Efek Indonesia Tahun 2012-2015, e-Journal S1 Ak Universitas Pendidikan Ganesha, Jurusan Akuntansi Program S1 (Vol: 6 No: 3 Tahun 2016)

Viandina Puspita, (2015) pengaruh economic value added (EVA) dan market value added (MVA) terhadap harga saham pada perusahaan kelompok lq-45 di bursa efek indonesia, Jembatan - Jurnal IImiah Manajemen Bisnis Dan Terapan Tahun XII No 2, Oktober 2015 